\title{
Preparation and characterization of etoricoxib- $\beta$-cyclodextrin complexes prepared by the kneading method
}

\author{
HARESH M. PATEL* \\ BHANUBHAI N. SUHAGIA \\ SHAILESH A. SHAH \\ ISHWAR SINH RATHOD \\ VIJAY K. PARMAR \\ Department of Quality Assurance \\ L. M. College of Pharmacy \\ Navrangpura, Ahmedabad-380009 \\ India
}

Accepted May 7, 2007

\begin{abstract}
The binary system of etoricoxib with $\beta$-cyklodextrin ( $\beta$-CD) was prepared by the kneading method. Drug-cyclodextrin interactions in solution were investigated by the phase solubility analysis. Differential scanning calorimetry, infrared spectroscopy, powder X-ray diffractometry and microscopic study were used to characterize the solid state of all binary systems, whereas their dissolution properties were evaluated according to the USP XXIII paddle method. The results indicate partial interaction of the drug with $\beta-C D$ in the physical mixture and complete interaction in the kneaded complex. The dissolution of etoricoxib was notably increased as compared to pure drug as well as its physical mixture. The complex showed more than $75 \%$ drug released in $30 \mathrm{~min}$.
\end{abstract}

Keywords: etoricoxib, cyclodextrin, complexation, kneading method

Etoricoxib (ET), 5-chloro-6'-methyl-3-[4-(methylsulfonyl)phenyl]-2,3'-bipyridine, a novel highly selective COX-2 inhibitor, is used for a variety of acute and chromic inflammatory diseases (1). However, its very low aqueous solubility and poor dissolution can cause formulation problems and limit its therapeutic application by delaying the rate of absorption and the onset of action (2). Solid dispersions of etoricoxib are reported with lipid carrier and polymers for improving dissolution $(3,4)$ Cyclodextrins are commonly used in drug formulations as solubility enhancers because of their ability to form water soluble inclusion complexes with poorly water soluble drugs $(5,6)$. Various anti-inflammatory drugs have been complexed with cyclodextrins, thus obtaining further advantages such as dose lowering, reduction of side effects (particularly gastric irritation) and taste masking $(7,8)$. The method of complexation may play a role in drug solubilization (9). Therefore, it seemed of interest to extend our investigations to a series of binary systems of etoricoxib with -cyclodextrin.

\footnotetext{
* Correspondence, e-mail: patelhary@rediffmail.com
} 
H. M. Patel et al.: Preparation and characterization of etoricoxib- $\beta$-cyclodextrin complexes prepared by the kneading method, Acta Pharm. 57 (2007) 351-359.

\section{EXPERIMENTAL}

\section{Materials}

Etoricoxib working standard was procured as a gift sample from Sun Pharmaceutical Industries Ltd., India. -cyclodextrin ( $\beta-C D)$ was procured as a gift sample from Cadila Pharmaceuticals Ltd., India. Methanol and potassium dihydrogen orthophosphate were purchased from S. D. Fine Chem. Pvt. Ltd., India.

\section{Phase solubility studies}

An excess of drug was added to $10 \mathrm{~mL}$ of water or -CD aqueous solutions (3-20 mmol L ${ }^{-1}$ ) in 25-mL stoppered conical flasks and shaken at room temperature on a magnetic stirrer (10). At equilibrium after 2 days, aliquots were withdrawn, filtered $(0.22 \mu \mathrm{m}$ pore size, Whatman UK) and spectrophotometrically assayed for drug content at 284.0 nm (Shimadzu UV- 160A Spectrophotometer, Shimadzu, Japan). The apparent 1:1 stability constant of the etoricoxib-cyclodextrin complex was calculated from the phase-solubility diagram:

$$
K_{\mathrm{c}}=\left(\text { slope } / S_{0}\right) \times(1-\text { slope })
$$

where $K_{\mathrm{c}}$ is the stability constant $\left(\mathrm{L} \mathrm{mol}^{-1}\right)$, slope is obtained from the linear relationship between the concentration of etoricoxib and $\beta-\mathrm{CD}$ and $S_{0}$ is etoricoxib solubility $\left(\mathrm{mmol}^{-1} \mathrm{~L}\right)$. Each experiment was carried out in triplicate $(R S D<3 \%)$.

\section{Preparation of physical mixtures and the solid inclusion complex}

For physical mixtures, ET and -cyclodextrin were weighed accurately at a 1:1 molar ratio, mixed thoroughly by trituration in a mortar and sieved through $0.25 \mathrm{~mm}$ sieve. All physical mixtures were stored in dessicator until further evaluation.

The inclusion complex of etoricoxib with $-C D$ was prepared at a 1:1 molar ratio by wetting the physical mixture in a mortar with a minimum volume of ethanol/water (1:1, by volume) mixture and kneading thoroughly with a pestle to obtain a paste, which was then dried under vacuum at room temperature, sieved through $0.25 \mathrm{~mm}$ sieve and stored in a dessicator until further evaluation.

\section{Inclusion efficiency}

The kneaded complex and its physical mixtures $(25 \mathrm{mg})$ were placed in $25-\mathrm{mL}$ volumetric flasks. Methanol $(10 \mathrm{~mL})$ was added, mixed thoroughly and sonicated for $30 \mathrm{~min}$. The volume was made up to the mark with methanol. The solution was suitably diluted with the same solvent and spectrophotometrically assayed for drug content at $284.0 \mathrm{~nm}$. Etoricoxib content was calculated as above. 
H. M. Patel et al:: Preparation and characterization of etoricoxib- $\beta$-cyclodextrin complexes prepared by the kneading method, Acta Pharm. 57 (2007) 351-359.

\section{Dissolution studies}

Dissolution studies were performed in phosphate buffer (pH 7.4, $900 \mathrm{~mL}$ ) at $37 \pm 0.2^{\circ} \mathrm{C}$, using USP XXIII apparatus (Electrolab, India) with a paddle rotating at $50 \mathrm{rpm}$ (11). Solid products, each containing $60 \mathrm{mg}$ of drug, were subjected to dissolution. At fixed time intervals, withdrawn samples were filtered (Whatman filter paper No. 41) and spectrophotometrically assayed for drug content at $284.0 \mathrm{~nm}$. Dissolution efficiency (DE) was calculated from the area under the dissolution curve at time $t$ (measured using the trapezoidal rule) and expressed as percentage of the area of the rectangle described by $100 \%$ dissolution in the same time (12).

\section{Differential scanning calorimetry (DSC)}

DSC analysis was performed using DSC (Model DT-60, Shimadzu). Samples (Shimadzu libror AEG 220 electronic balance, 5-7-mg) were heated in open aluminium pans at a rate of $10{ }^{\circ} \mathrm{C} \mathrm{min}-1$ in a $0-300{ }^{\circ} \mathrm{C}$ temperature range under a nitrogen steam. The instrument was calibrated using indium (melting point, $156.61^{\circ} \mathrm{C}$; enthalpy of fusion, $28.71 \mathrm{~J} \mathrm{~g}^{-1}$ ).

\section{$X$-ray powder diffractometry (XRPD)}

X-ray powder diffraction patterns were recorded on an X-ray diffractometer (Model X"Pert, Philips, the Netherlands) using Ni-filtered, Cu K radiation, voltage of $40 \mathrm{kV}$ and $25 \mathrm{~mA}$ current. The scanning rate employed was $1^{\circ} \mathrm{min}^{-1}$ over the $0-100^{\circ}$ diffraction angle (20) range.

\section{Fourier transform infrared (FTIR) spectroscopy}

FTIR spectra were recorded on samples prepared in $\mathrm{KBr}$ using FTIR-8400S with IR solution software (Shimadzu). Data were collected over a spectral region from 4000 to $650 \mathrm{~cm}^{-1}$ with resolution $4 \mathrm{~cm}^{-1}$ and 100 scans.

\section{RESULTS AND DISCUSSION}

\section{Preliminary studies}

The complexation of etoricoxib with $\beta$-CD was studied at molar ratios of 1:0.5, 1:1.0, $1: 1.5,1: 2.0,1: 2.5$, and 1:3.0. The complexes were prepared by the kneading method and were characterized by inclusion efficiency, dissolution, wettability and HPTLC studies. All complexes showed increased dissolution efficiency, reduced time required for $50 \%$ drug to be dissolved and improved wettability (less wetting time, 76-45 min, compared to pure drug) and almost constant inclusion efficiency. HPTLC of the complex suggested only one component in prepared systems (data not shown).

Higher dissolution (> 75\% released in $30 \mathrm{~min}$ ) was obtained using a 1:1 molar ratio of the drug to $\beta-\mathrm{CD}$. Therefore further investigations were carried out for the 1:1 molar ratio. 


\section{Phase solubility}

Etoricoxib is a sparingly soluble drug. The solubility of etoricoxib in distilled water at $\mathrm{pH} 6.8$ at room temperature was $24.0 \mathrm{\mu g} \mathrm{mL}^{-1}$ and was notably affected by the presence of $\beta$-CD. Solubility of ET in $4 \mathrm{mmol} \mathrm{L}^{-1} \beta-\mathrm{CD}$ aqueous solution was $0.025 \mathrm{mmol} \mathrm{L}^{-1}$ while it was $0.045 \mathrm{mmol} \mathrm{L}^{-1}$ in $20 \mathrm{mmol} \mathrm{L}^{-1} \beta-\mathrm{CD}$ solution. The obtained phase solubility diagram was linear (Fig. 1) and could be classified as $A_{L}$ type according to Higuchi and Connors (10). The slope of solubility diagram was less than one; it was therefore assumed that the solubility increase could be attributed to the formation of the 1:1 complex.

Stability constant value obtained for the etoricoxib-CD complex was $170.13 \mathrm{~L} \mathrm{~mol}^{-1}$, which indicated that the etoricoxib- $\beta$-cyclodextrin complex at a 1:1 ratio is adequately stable (10).

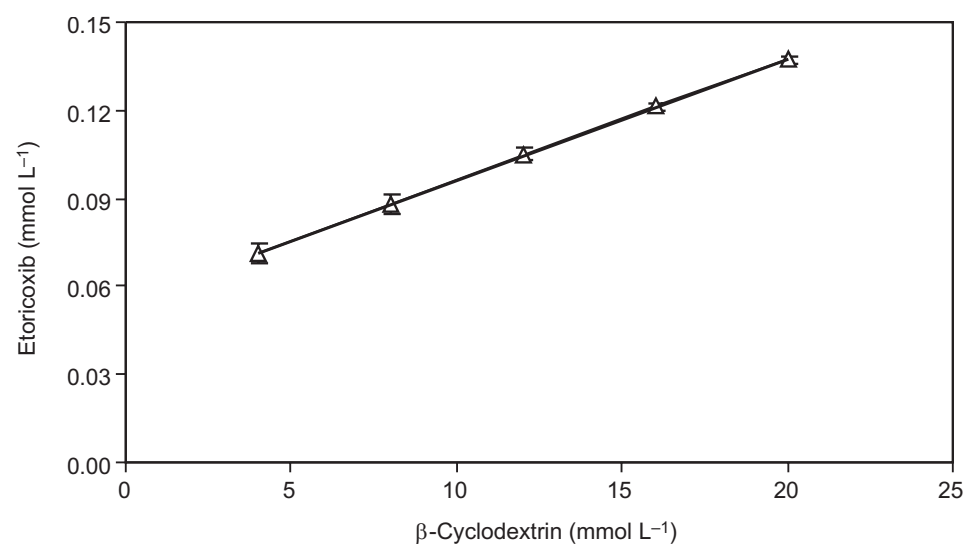

Fig. 1. Phase solubility diagram of etoricoxib in $3-15 \mathrm{mmol} \mathrm{L}^{-1} \beta$-cyclodextrin aqueous solution $($ mean $\pm \mathrm{SD}, n=3)$. Linear equation is $\mathrm{y}=0.0041 \mathrm{x}+0.0547)(R=0.9988)$.

\section{Inclusion efficiency}

The percentage of etoricoxib in the samples ranged from $98.2 \pm 0.2$ to $100.2 \pm 0.1$ $(n=3)$, as reported in Table I. This indicated that etoricoxib was uniformly distributed in all the samples.

\section{Dissolution}

The in vitro dissolution profiles of the drug, physical mixture and inclusion complex are shown in Fig. 2. The dissolution of complexes was higher compared to the drug alone. The dissolution profile of the kneaded complex (1:1 molar ratio showed $80.0 \%$ drug released in 30 min while that of the 1:1 physical mixture and pure drug showed $50.8 \%$ and $40.7 \%$, respectively. This enhancement can be attributed to the higher hydrophilic character of the systems due to the presence of the carrier, which can reduce the interfacial 
H. M. Patel et al.: Preparation and characterization of etoricoxib- $\beta$-cyclodextrin complexes prepared by the kneading method, Acta Pharm. 57 (2007) 351-359.

Table I. Inclusion efficiency, dissolution efficiency, $\mathrm{t}_{50}$ and wetting time of the drug and its preparations ${ }^{a}$

\begin{tabular}{lcccc}
\hline Type & $\begin{array}{c}\text { Inclusion } \\
\text { efficiency }(\%)\end{array}$ & $\begin{array}{c}\text { Dissolution efficiency } \\
\text { in } 120 \mathrm{~min}(\%)\end{array}$ & $t_{50}(\mathrm{~min})$ & $\begin{array}{c}\text { Wetting time } \\
(\mathrm{min})\end{array}$ \\
\hline Drug & $100.2 \pm 0.1$ & $47.3 \pm 1.0$ & $59.9 \pm 2.4$ & $149.0 \pm 1.0$ \\
$1: 1$ kneaded complex & $98.2 \pm 0.2$ & $77.9 \pm 0.3$ & $3.7 \pm 0.0$ & $69.5 \pm 1.0$ \\
1:1 physical mixture & $99.5 \pm 0.2$ & $62.7 \pm 0.7$ & $7.2 \pm 0.1$ & $73.5 \pm 1.0$ \\
\hline
\end{tabular}

a Mean $\pm \mathrm{SD}, n=3$.

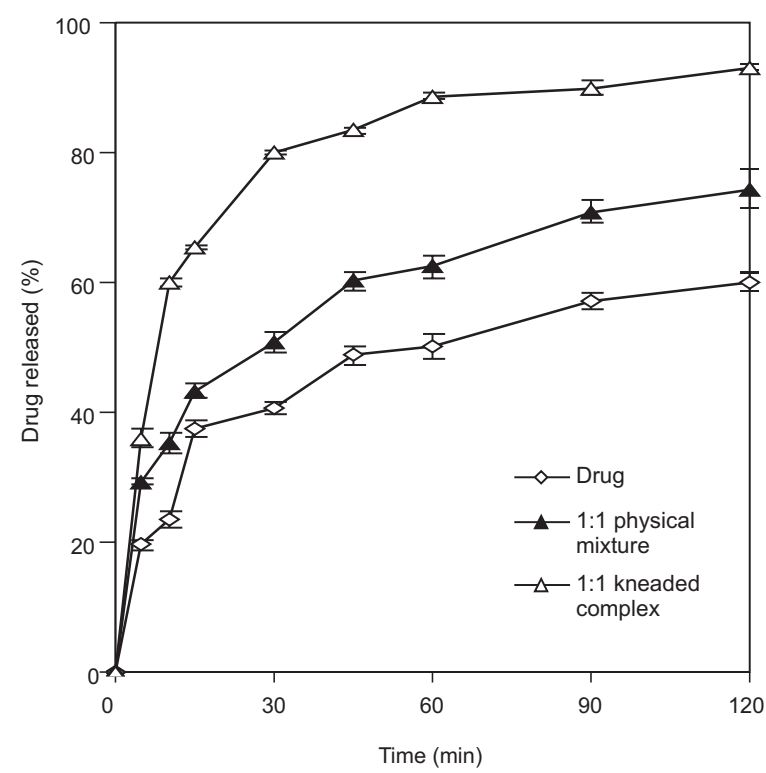

Fig. 2. Dissolution profile of etorico$\mathrm{xib}$ and its preparations (mean $\pm \mathrm{SD}$, $n=3)$.

tension between the poorly water soluble drug and the dissolution medium (14). Moreover, in the case of $\beta-C D$, in the early stage of the dissolution process, the carrier dissolves more rapidly than the drug. Hence, it can act on the hydrodynamic layer surrounding the drug particles, resulting in an in situ inclusion process that improves the dissolution of the drug (14). In fact, the systems containing a larger amount of $\beta-C D$ showed faster drug dissolution. It must be pointed out that the 1:1 kneaded complex showed improved drug dissolution compared to its physical mixture. As shown above, the kneaded complex showed 1.6 time higher dissolution in 30 min than the physical mixture.

$D E$ values and the time taken for $50 \%$ dissolution $\left(t_{50}\right)$ based on the dissolution data were calculated according to the Khan method (12) (Table I). Also, all the complexes of ET with $\beta$-CD exhibited higher $D E_{120}$ values ( $D E$ for $120 \mathrm{~min}$ ) than ET itself and its physical mixture, namely 77.9 vs. 62.7 and $47.3 \%$ respectively. Therfore, the 1:1 kneaded 
complex and 1:1 physical mixture showed 1.7 and 1.3 times higher dissolutions efficiency compared to pure drug in $120 \mathrm{~min}$. The $D E_{120}$ values increased as the proportion of $\beta-C D$ in complexes was increased.

DSC

DSC curves of the pure drug, $\beta$-CD, 1:1 molar physical mixture and 1:1 molar kneaded complex are shown in Fig. 3. DSC curve of the drug showed a sharp endothermic peak at $140.68{ }^{\circ} \mathrm{C}$ corresponding to the melting point of etoricoxib. DSC curve of $\beta-\mathrm{CD}$ showed a slightly sharp endothermic peak at $148.59^{\circ} \mathrm{C}$ corresponding to the melting point of $\beta$-CD. DSC curve of the 1:1 molar ratio physical mixture of the drug and $\beta-C D$ showed two broad endothermic peaks, one broad peak at $130.74{ }^{\circ} \mathrm{C}$ corresponding to etoricoxib and another broad peak at $139.18^{\circ} \mathrm{C}$ corresponding to $\beta$-CD. DSC curve of the 1:1 molar ratio kneaded complex of the drug and $\beta$-CD showed two broad endothermic peaks, one broad peak at $133.20^{\circ} \mathrm{C}$ corresponding to etoricoxib and another broad peak at $150.99{ }^{\circ} \mathrm{C}$ corresponding to $\beta-\mathrm{CD}$. Peak temperatures in the physical mixture and kneaded complex were slightly shifted with respect to the drug alone.

The $\Delta H$ values of the drug, $\beta-C D$, physical mixture and its complex were found to be $-88.52,-78.74,-40.27$ and $-22.45 \mathrm{~J} \mathrm{~g}^{-1}$, respectively. The reduction of the kneaded complex $\Delta H$ value compared to the pure drug and physical mixture could be attributed to the amorphous form of the drug in the complex.

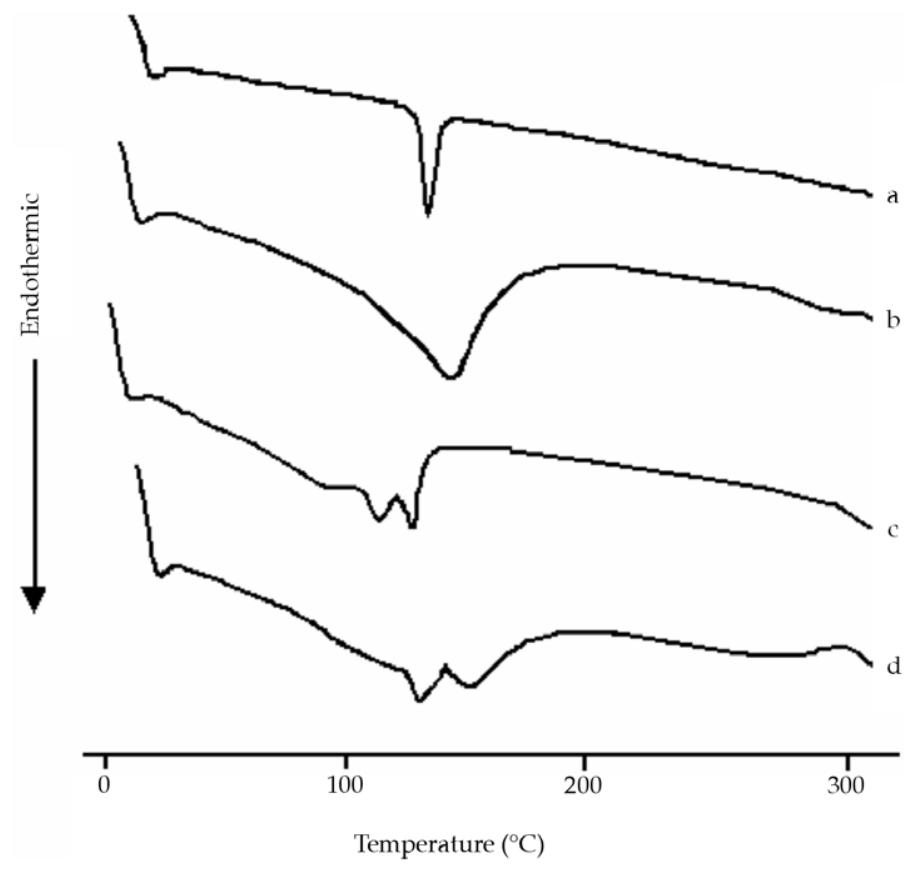

Fig. 3. DSC thermograms of: a) drug, b) $\beta-C D$, c) 1:1 physical mixture and d) 1:1 kneaded complex. 


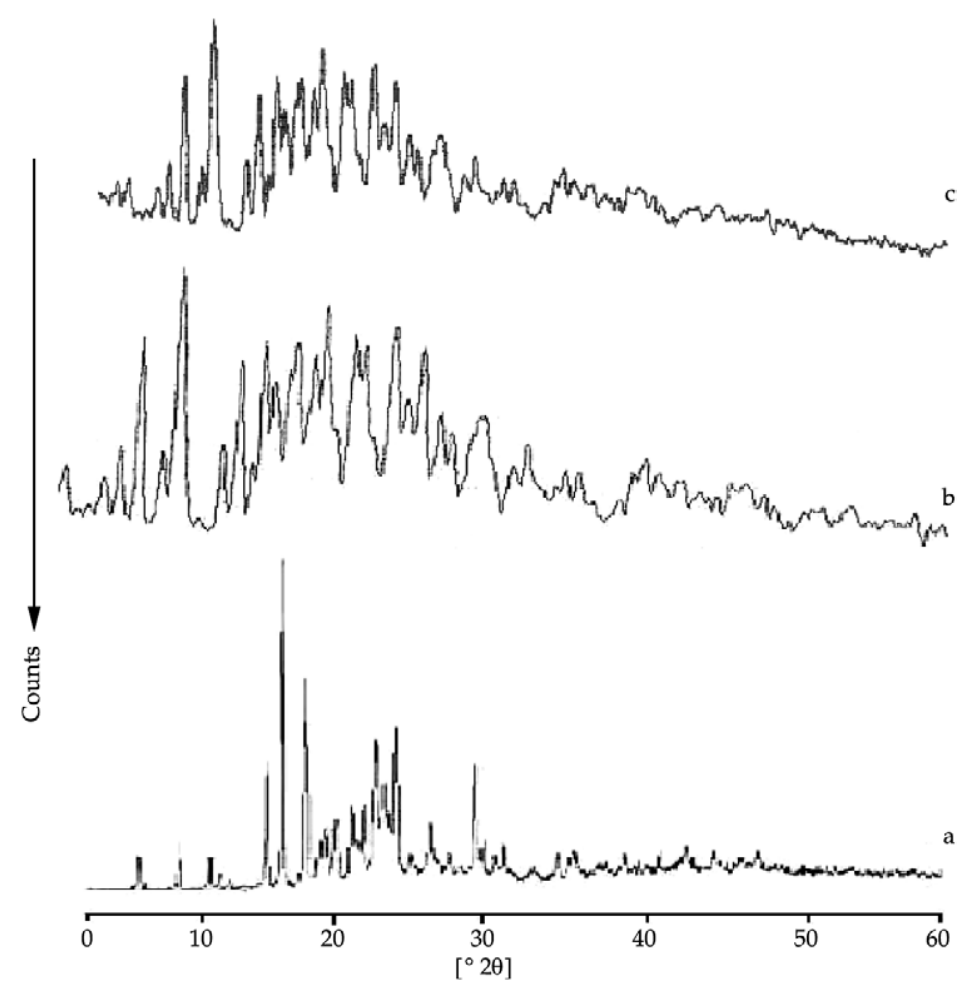

Fig. 4. XRD of: a) drug, b) 1:1 physical mixture and c) 1:1 kneaded complex.

\section{$X R P D$}

The X-ray diffraction patterns of the drug, 1:1 physical mixture and 1:1 kneaded complex are presented in Fig. 4. Characteristic peaks appeared in the XRPD pattern of the drug alone, suggesting that the drug is present as a crystalline material. All the peaks of etoricoxib in the complex showed lower intensity compared to the pure drug and physical mixture. This result indicated that the drug in the complex is completely amorphous compared to the pure drug as well as physical mixture.

\section{FTIR}

The FTIR spectra of pure etoricoxib showed characteristic peaks at $1598.9 \mathrm{~cm}^{-1}(\mathrm{C}=\mathrm{N}$ stretching vibration), 1433.0, 1300.0, 1130.2 and $1083.9 \mathrm{~cm}^{-1}$ ( $\mathrm{S}=\mathrm{O}$ stretching vibration) and $839.0,781.1$ and $638.0 \mathrm{~cm}^{-1}(\mathrm{C}-\mathrm{Cl}$ stretching vibration). The spectrum of pure $\beta-\mathrm{CD}$ showed characteristic peaks at 3290.3 and $3230.5 \mathrm{~cm}^{-1}$. The spectrum of the physical mixture is exactly matched with the $\beta-C D$ spectra and the crystalline drug spectrum. This indicated that no interaction occurred during simple physical mixing of the drug and $\beta-C D$. The complexes of etoricoxib with $\beta-C D$ revealed a shift and slight broadening of 
H. M. Patel et al.: Preparation and characterization of etoricoxib- $\beta$-cyclodextrin complexes prepared by the kneading method, Acta Pharm. 57 (2007) 351-359.

$\mathrm{S}=\mathrm{O}$ stretching vibration $\left(1080.1 \mathrm{~cm}^{-1}\right)$ peak of etoricoxib and $\mathrm{O}-\mathrm{H}$ stretching vibration peaks (3344.3 and $3290.3 \mathrm{~cm}^{-1}$ ) characteristic of the carrier. These observations might indicate the possibility of intermolecular hydrogen bonding via the $\mathrm{S}=\mathrm{O}$ group of etoricoxib and $\mathrm{OH}$ group of $\beta-\mathrm{CD}$.

\section{Wettability}

The wetting time (13) for the drug, its physical mixture and its complex is presented in Table I. The wetting time of the drug was found to be $149.0 \mathrm{~min}$ while that of the complex (1:1 molar ratio) was found to be $69.5 \mathrm{~min}$. These observations might indicate that the drug in systems was more hydrophilic and more easily wettable compared to pure drug in the dissolution medium. Increased wetting of the particles may be considered to be a major contributor to the enhanced etoricoxib dissolution from the complex system containing $\beta-C D$.

\section{CONCLUSIONS}

The dissolution profile of the kneaded complex (1:1 molar ratio) showed more than $75 \%$ drug released in $30 \mathrm{~min}$. Further study is required to prepare a prompt release oral formulation of etoricoxib by utilizing this complex.

Acknowledgements. - The authors acknowledge Sun Pharmaceutical Industries Ltd. and Cadila Pharmaceuticals Ltd., India, for providing gift samples of the drug and $\beta-C D$, respectively.

\section{REFERENCES}

1. P. Leclercq and M. G. Malaise, Etoricoxib (Arcoxia), Rev. Med. Liege 59 (2004) 345-349.

2. D. J. Cochrane, B. Jarvis and G. M. Keating, Etoricoxib, Drugs 62 (2002) 2637-2651.

3. B. Chauhan, S. Shimpi and A. Paradkar, Preparation and characterization of etoricoxib solid dispersions using lipid carriers by spray drying technique, AAPS PharmSciTech. 6 (2005) 405-412; DOI: $10.1208 / \mathrm{pt} 060350$.

4. B. N. Suhagia, H. M. Patel, S. A. Shah, I. S. Rathod and V. K. Parmar, Preparation, characterization and in vitro dissolution of etoricoxib-polyethylene glycol 4000-polyvinyl pyrrolidone K30 solid dispersions, Acta Pharm. 56 (2006) 285-298.

5. T. Loftsson and M. Brewster, Pharmaceutical application of cyclodextrins. I. Drug solubilization and stabilization, J. Pharm. Sci. 85 (1996) 1017-1025; DOI: 10.1021/js950534b.

6. R. A. Rajewski and V. J. Stella, Pharmaceutical application of cyclodextrins II. In vivo drug delivery, J. Pharm. Sci. 85 (1996) 1142-1169; DOI: 10.1021/js960075u.

7. K. H. Fromming and J. Szejtli, Cyclodextrins in Pharmacy, Kluwer Academic Publishers, Dordrecht 1994.

8. K. Uekama, F. Hirayama and I. Tetsumi, Cyclodextrin drug carrier systems, Chem. Rev. 98 (1998) 2045-2076; DOI: 10.1021/cr970025p.

9. G. P. Betteinetti, A. Gazzania, P. Mura, F. Giordano and M. Setti, The thermal behaviour and dissolution properties of naproxen in combinations with chemically modified $\beta$-cyclodextrins, Drug Dev. Ind. Pharm. 18 (1992) 39-53. 
H. M. Patel et al:: Preparation and characterization of etoricoxib- $\beta$-cyclodextrin complexes prepared by the kneading method, Acta Pharm. 57 (2007) 351-359.

10. T. Higuchi and K. A. Connors, Phase solubility techniques, Adv. Anal. Chem. Instrum. 4 (1965) 207-212.

11. USP XXIII, NF XVIII, USP Convention, Rockville 1995, pp. 1791-1799.

12. K. A. Khan and C. T. Rhodes, The concept of dissolution efficiency, J. Pharm. Pharmacol. 27 (1975) 48-49.

13. C. Lefebvre, A. M. Barthelemy and G. Hermann, An attempt at bringing to light a phase inversion in a binary mixture of two dimensional rounded particles, Drug Dev. Ind. Pharm. 14 (1988) 2443-2465.

14. P. Mura, M. T. Faucci and P. L. Parrini, Effects of grinding with microcrystalline cellulose and cyclodextrins on the ketofen physicochemical properties, Drug Dev. Ind. Pharm. 27 (2001) 119-128;

DOI: $10.1081 /$ DDC-100000478.

$S A \check{Z} E T A K$

Priprava kompleksa etorikoksiba s $\beta$-ciklodekstrinom metodom gnječenja i njihova karakterizacija

HARESH M. PATEL, BHANUBHAI N. SUHAGIA, SHAILESH A. SHAH, ISHWAR SINH RATHOD i VIJAY K. PARMAR

Metodom gnječenja pripravljen je binarni sustav etorikoksiba s $\beta$-ciklodekstrinom ( $\beta$-CD). Tijekom 30 minuta iz kompleksa se oslobodilo više od $75 \%$ ljekovite tvari, što je značajno više u odnosu na fizičku smjesu etorikoksiba i $\beta$-CD ili čistu ljekovitu tvar. Interakcije lijeka i ciklodekstrina $u$ otopini ispitivane su analizom fazne topljivosti. Za karakterizaciju čvrstog stanja svih binarnih sustava korištena je diferencijalna pretražna kalorimetrija, infracrvena spektroskopija, difrakcija rentgenskih zraka na praškastom uzorku i mikroskopija. Oslobađanje je praćeno metodom lopatice prema USP XXIII. Rezultati ukazuju na djelomičnu interakciju ljekovite tvari s $\beta$-CD u fizičkoj smjesi te potpunu interakciju u kompleksu.

Ključne riječi: etorikoksib, ciklodekstrin, kompleksacija, metoda gnječenja

Department of Quality Assurance, L. M. College of Pharmacy, Navrangpura, Ahmedaba-380 009, India 